\title{
Economic Aspects of COVID-19 Medical Crisis
}

\author{
Gabriel Căriman ${ }^{1 *}$ \\ Dumitru-Mihai Luca²
}

\begin{abstract}
The present analysis focuses on the context of the SARS-CoV-2 pandemic, a context in which the state governments of the world have adopted measures trying to limit the spread of the virus, with the risk of affecting the economy in the long run. The oil industry has faced declining oil prices, which has had consequences for other industries, such as tourism, HoReCa and transportation. The pandemic with the COVID-19 virus also had a devastating impact on air traffic, the number of flights decreasing considerably due to the traffic restrictions that were imposed. Last but not least, tourism is another sector affected by the pandemic, due to the lack of tourists, thus causing effects on other economic sectors. Some of the effects of the measures adopted in the context of the pandemic have already occurred, and others are about to occur, being of impact and duration. The article underlines the impact of the January-June 2020 pandemic on the oil industry, air traffic and tourism and provides an overview of the challenges which governments need to address together with economic operators in order to regain public confidence to facilitate consumer decisions and for economic recovery.
\end{abstract}

Keywords: COVID-19 crisis, oil industry, air traffic, tourism, government measures

JEL Classification: H12, L39, L95, L98, Z390

DOI: $10.24818 / \mathrm{REJ} / 2021 / 79 / 03$

\section{Introduction}

In order to prevent the spreading of the virus, world governments have issued a series of measures to limit the spread of the pandemic, which means limiting the actual exit of households, canceling all events involving people gatherings, closing commercial spaces and closing land and air borders. All these measures translate into economic losses recorded by economic agents which, due to social distancing measures and with the closure of borders face disruptions in the supply flow which implicitly cause increases in the price of the finished product obtaining the

${ }^{1}$ Faculty of Economics and Business Administration, „Alexandru Ioan Cuza” University of Iasi 700506, Romania, cariman.gabriel@gmail.com

2 Faculty of Economics and Business Administration, „Alexandru Ioan Cuza” University of Iasi, 700506, Romania, lucadumitrumihai92@gmail.com

* Corresponding author.

Year XXIV no. 79

March 2021 
quality of "rarity". For example, both airlines and land carriers are facing declining demand which will be reflected in cost reduction measures. The lack of passengers determines the companies operating in this industry to stop their activity, thus immobilizing their resources, their storage implying enormous costs. The tourism industry, which is dependent on the transport industry, is facing a decrease in the number of tourists. In the case of some states, such as Greece or Turkey, where tourism is the "locomotive" of the economy, increased economic disruptions may occur due to declining demand for services. Also, a side effect faced by employers in the tourism industry is the "avalanche" of requests to cancel vacations and refund the amounts paid for them. The hospitality industry is another industry with implications for the indicator of GDP growth per capita. Like the industries mentioned above, it depends directly on the free movement of the population and implicitly of the customers, their lack leading to lower revenues, inability to pay, staff restructuring measures and, in some cases, business closures due to the effects of COVID-19 virus.

The cessation of either partial or total economic activity in certain sectors has led to the elimination from the market of some economic agents who, due to lack of customers, cannot honor their payments to suppliers of raw materials, rents and loans. These issues have also generated negative effects on the labor market where a number of redundancies have been registered, and to limit these negative effects generated by redundancies, some governments have come to the aid of companies and citizens by supporting the salaries of the employees sent into technical unemployment, in a certain percentage or by extending / postponing the payment periods for certain taxes and duties, all these measures leading to an increase in budget expenditures.

On the other hand, financial-banking institutions have aligned themselves with the new conditions by also adopting a series of measures in partnership with state governments offering state-guaranteed loans or postponing the payment of installments for a certain period of time in the case of the unemployed. However, in parallel, banks have also taken self-protection measures by increasing advances in loans, because the risk assumed in the context of the pandemic is high, given that a significant number of people and businesses have got into default.

\section{Problem Statement}

The global pandemic triggered by the SARS-CoV-2 virus has led scientists in various fields to focus their research in a short period of time in order to identify the effects and fix the repercussions generated by this broad challenging context

Year XXIV no. 79

March 2021 
for the 21st century. Also, the primary intervention to limit the effects of the crisis has been undertaken by world governments. Far from being considered a "black swan" type event as many authors claim and as Nicholas Taleb (2020) himself dismantles, COVID-19 actually caught the system's inability to take concrete action to prevent and limit some risks identified with the 2009 pandemic. It is important to note that there have been several warnings over time highlighting that pandemics pose a major threat to society and tourism, according to Gössling (2002)., Hall (2006, 2020), Page \& Yeoman (2007), Scott \& Gössling (2015), National Academies of Sciences, Engineering, and Medicine (2017, 2018), but also World Bank (2012).

In this context, the measures taken to protect the health of the population have mainly led to restrictions on freedom of travel. As Burkle (2006) argues, the relationship between pandemics and travel is essential to understand global health security and change. The panic has inevitably led to a narrowing of the tourism sector (Shretta, 2020) with direct effects in other sectors of the economy as well. According to WTTC (2020), in 2019 tourism accounted for $10.3 \%$ of global GDP, $6.8 \%$ of total exports and $28.3 \%$ of export services, the SARS-CoV-2 pandemic generating over $\$ 820$ billion losses globally (Ozili \& Arun, 2020). The quarantine measures imposed to minimize the spread of the virus have affected, as in a game of dominoes, the airlines, which have had to significantly reduce their traffic values in a favorable context for them, where the trend of global mobility had increased in the last decade at a faster rate than the global population growth (Recchi et al., 2019). At the same time, regarding the oil industry, as Nicola et. al. (2020) state, amid this crisis that is diminishing oil demand, misunderstandings about the price of oil will intensify; a low price with the current serious implications for the global economy in the context in which the restrictions imposed by governments and the uncertainties generated by job security will not generate increases in consumption.

\section{Research Questions}

The COVID-19 virus pandemic is why states have tried to take measures to limit the outbreak of the virus. Although the measures that were adopted had as a top priority the health and safety of people, the effects they have determined in different economic sectors cannot be ignored. The measures adopted consisted primarily of traffic restrictions, which is why they had their effects, in the first phase, on the oil industry, on air traffic and on tourism. The present analysis considers these three sectors and tries to capture the main impact that occurred at their level.

Year XXIV no. 79

March 2021 


\section{Research Methods}

This paper is based on documentary research, a series of documents such as books, scientific articles, analysis or studies being carefully analyzed. We have tried to create a theoretical framework through which to highlight the impact of the SARS-CoV-2 crisis on different sectors, respectively on the oil industry, air traffic and tourism. We consider that the COVID-19 crisis is a topical and very complex issue, the impact being evolving, and the analysis of current and future effects is required for a correct and efficient approach to solutions.

In the analysis we used tools such as tables and graphs that contributed to a better highlighting of the researched aspects.

\section{Findings}

The research focuses on the oil industry, air traffic and tourism and aims to highlight the measures ordered in these sectors by governments in the context of the COVID-19 pandemic and expose briefly the current and potential effects of these measures.

\subsection{Analysis of the oil industry}

The oil industry has its well-defined role in the economic mechanism. Today, the movement of people and goods is largely done by transport means that use fuels, an interdependence existing between the oil industry and the transport industry. Thus, the instability of this industry can lead to a chain price rise of the products and, implicitly, to triggering or fueling of economic crises. The report (World Bank, 2020) presents the evolution of the price of a barrel of oil between January and May 2020, which was transposed in the figure no. 1.

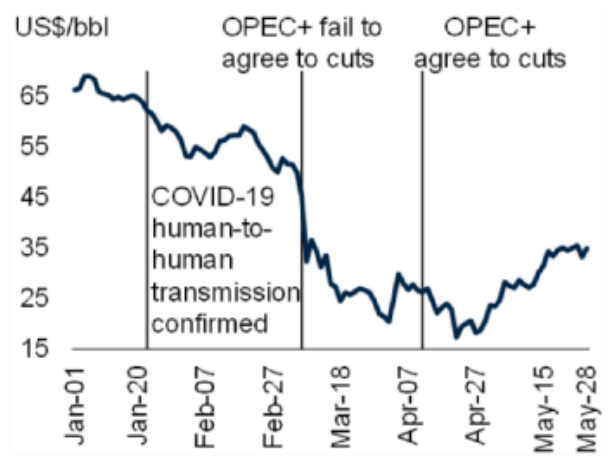

Figure 1. The evolution of the price of a barrel of oil during Jan.-May 2020. Source: Global Economic Prospects (a World Bank Flagship Report), page. 22

Year XXIV no. 79

March 2021 
Commodity prices declined considerably in the first half of 2020, mainly due to lower demands as a result of the COVID-19 virus pandemic and to disruptions experienced by economic operators in the supply chain. However, the chart above shows that a sharp decline was also felt within the oil industry, where the price of oil was up to $\$ 17.3$ / barrel in April. This decline in oil prices reflects disruptions within other industries such as tourism, hospitality industry and transport, which have been hit by declining demand, thus influencing oil demand as well. Travel restrictions, social distancing measures by increasingly limiting exits and contact between people, have led to a reduction in both urban and extra-urban travel and exits which have been transposed by a declining demand for fuel, so that the price oil has been on a downward trend since early January, on the background of spreading of the COVID-19 virus pandemic. In order to revive this fall in oil prices as a result of the global fall in demand, the Organization of the Petroleum Exporting Countries (OPEC) has initiated a series of discussions to conclude an agreement aimed at reducing production for the member states within this organization. At the end of 2019, the agreement called "OPEC +", one that also includes Russia in the mechanism for setting production quotas, managed to bring the price of oil on an upward trend, from a price of 27 dollars / barrel to about 60 dollars. However, the first series of talks initiated by Saudi Arabia on reducing oil production in order to maintain a higher price per barrel, was met with a refusal from Russia because it managed to reach a budget deficit close to 0 , with a price per barrel of oil between 40 and 45 dollars. In contrast, for Saudi Arabia, the price of a barrel is over $\$ 80$, this price being determined by the massive investments planned before the onset of a health crisis. In fact, Russia's choice not to reduce oil production is also determined by the fact that it uses outdated technologies, so that a "restart" of the industry requires long costs and time that can jeopardize investment plans in modernizing the oil industry. Despite these misunderstandings, on April 9th, 2020, a "historic" agreement was reached between the OPEC states and Russia to reduce oil production, thus ending a "war" of market share. Thus, the agreement initiated aimed at reducing oil production by 10 million barrels / day, with Russia and Saudi Arabia bearing half of the value, respectively 2.5 million barrels / day for each of the two major powers in the oil industry, this value being higher than the agreement reached in March by Saudi Arabia. Therefore, once this agreement was concluded, the value of the oil price continued to decline until the end of April, when the first positive signs of the agreement appeared, which translates into an upward price trend of $\$$ 34.9 / barrel as of May 28th, 2020, doubled in value from an all-time low of $\$ 17.3$ / barrel in history.

Year XXIV no. 79

March 2021 
The global context generated by COVID-19 will continue to put pressure on the oil industry even if the measures of traffic restriction are gradually lifted. This is mainly due to the declining consumption, and a recovery in the oil industry will be all the more difficult as renewable energy sources posed a threat even before the pandemic broke out, and they are increasingly accepted among the population, being encouraged by the governments of the world.

\subsection{The evolution of air traffic}

The evolution of air industry and transportation has seen an upward trend in recent decades. Today, the benefits of air transport are many, from transporting people and goods to defense and security. All this contributes to world economic growth and development. With the help of the data provided by (ICAO, 2020) we managed to analyze the impact that the pandemic with the COVID-19 virus has on air traffic, impact transposed in figure no. 2 below.

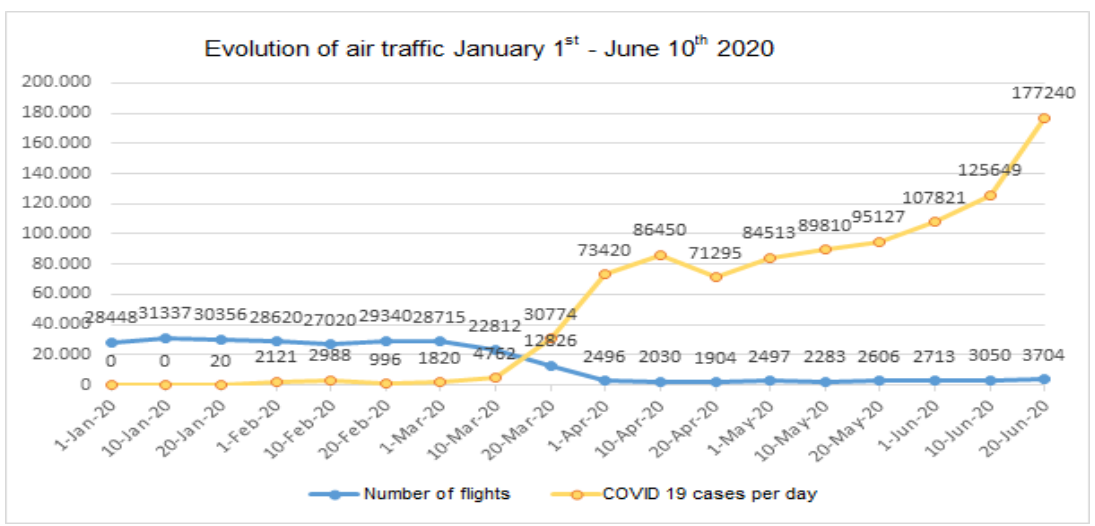

Figure 2. Evolution of air traffic correlated with the number of COVID-19 cases during January - June 2020.

Source: Own processing after: Global COVID-19 Airport Status, accessed at: https://www.icao.int/safety/pages/covid-19-airport-status.aspx

Air transport has experienced an upward trend in recent decades, with the number of passengers increasing from year to year, becoming an increasingly accepted means of transport by companies that use cargo flights to sell products on other continents, thus saving time. Precisely the advantages of reduced travel time and the title of "safest means of transport" has transformed the aviation industry into an industry that generates profits of billions of euros and millions of jobs. 
The data presented above come as a confirmation of the devastating effects of the COVID-19 virus pandemic on transport and the aviation industry. As mentioned above, the aviation industry is one of the industries with direct influences on the economy. The disruptions in this industry can create real economic imbalances with effects on the level of the unemployment rate and on the business environment, resulting from the disruption of the supply chains of economic agents. Therefore, air traffic in January 2020, a month that coincides with the onset of the pandemic generated by COVID-19 in Asia, on January 20th, 2020 the first 20 cases being recorded, was totaling an average of about 30,000 flights per day. Once the virus has spread to China and Asia, it can be seen that the number of flights has started to decrease in the affected area, this decrease being the result of the first traffic restriction measures imposed by the authorities. As of February 1 st, 2020, the number of flights decreased to 28,620 per day worldwide, compared to a number of 2,121 cases of COVID-19 identified per day. The lack of air restrictions imposed from the beginning has led to the outbreak of a pandemic, with every corner of the world being affected as a result of air connections between continents. As of March 1st, 2020, the number of flights was around 28,715 compared to 1,820 new cases identified that day. 10 days later, the evolution of the pandemic determines the authorities to implement the first measures to restrict the movement of people by air, on March 10th, 2020, 22,812 flights were registered and a number of 4,762 new cases of COVID-19 virus. Between March 10th and March 20th, many states began imposing restrictions on air traffic and the free movement of people, measures to prevent the spread of the pandemic. As of March 20th, 2020, the number of flights worldwide was 12,826, compared to 30,774 new cases that occurred on that date. With April 2020, the number of commercial flights was drastically reduced due to the increasing evolution of the number of cases, so on April 1st, 2020 an unprecedented decrease was reached, with 2,496 flights per day compared to a number of 73,420 of new cases for that day. During the period April-May 2020 (considered the peak but also the "first wave" of the pandemic) the number of registered flights stood at an average of about 2,500 per day, compared to an average of 80,000 new cases per day. Starting with June 2020, the world's economies began to relax social distancing measures, and amid the "restart of economies", air traffic began to resume its activity slowly, despite the fact that the number of new COVID-19 cases is on an upward trend. Thus, on June 10th, an average of 3,050 flights per day were registered, compared to a number of 125,649 new cases per day, while on June 20 th, a number of 3,704 flights per day were registered, relative to a number of 177,240 new cases of COVID-19 virus for that day.

Year XXIV no. 79

March 2021 
The effects of the COVID-19 pandemic on the aviation industry affect all sectors, especially tourism and the hospitality industry, which relies on tourists to use flights to reach destinations. Also, with the restrictive measures imposed by the authorities, companies operating in the automotive industry were forced to stop their activities due to lack of demand, a situation that generated losses of billions of euros and firing or sending the employees to technical unemployment, which led to an increase in the unemployment rate. The return of air traffic values to those prior to the pandemic will be difficult given the persistence of uncertainties among the population regarding flight safety. The additional measures taken to ensure safer flights from a health point of view will bring improvements to the sector, but they will not be as fast compared to the decline triggered by the pandemic, especially as the overall impact has also created uncertainty on the financial prospects of passengers.

\subsection{Tourism analysis}

Tourism is another sector affected by this pandemic. In the case of states such as Greece, tourism plays a key role in the economic well-being of the country, this sector being considered a real "economic engine". With the emergence of restrictions aimed at limiting the travel of citizens, this sector has been in decline due primarily to the lack of tourists. With the help of the reports (UNWTO, 2020) we managed to analyze the impact that the pandemic with the COVID-19 virus has on tourism, referring to the number of tourists arriving between January and June 2020, information that was formalized in the figure no. 3 below:

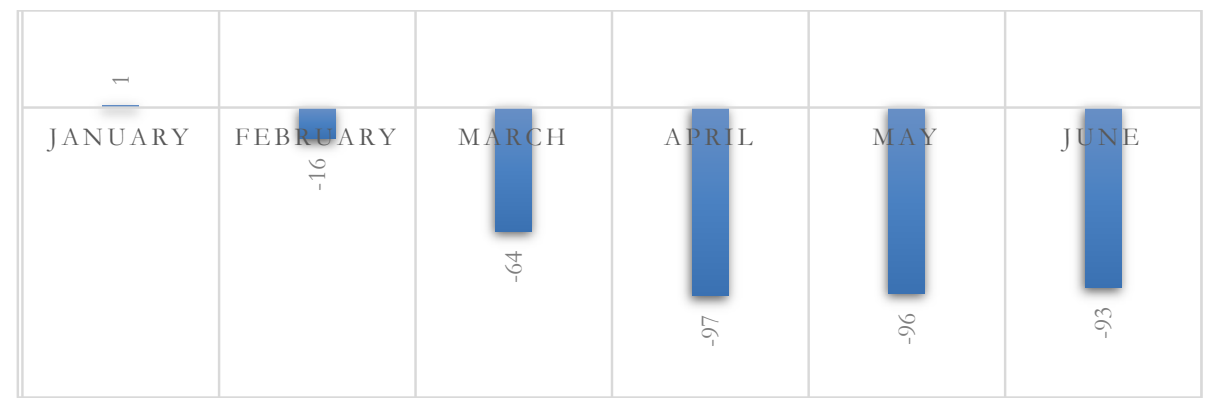

Figure 3. The evolution of global tourism between January and June 2020

Source: Own processing after: International Tourism and COVID-19, accessed at: https://www.unwto.org/international-tourism-and-covid-19

The pandemic triggered by the COVID-19 virus led to the "paralysis" of the tourism industry, as well as of the hospitality industry. The graph above shows the 
evolution of arrivals for tourism worldwide. Thus, as we can see, January (considered the beginning of the pandemic with the COVID-19 virus) represents the only month in which the values are positive. The first signs of the negative effects of the pandemic on tourism appear in February, when there was a $16 \%$ decrease in tourist travel, this figure being determined by the first measures applied in Asian countries, aimed at stopping the evolution of this virus. March also coincides with the time when the COVID-19 virus is making its global presence felt and the time when most countries in the world are adopting movement restriction and social distancing measures. These measures adopted gradually during March by the states of the world are well aware of the expected effects so, for April and May, the decrease of tourist arrivals was a drastic one, $97 \%$ and $96 \%$ respectively. A slightly positive development, which is attributed to the relaxation of social distancing measures and restrictions on the movement of people, can be observed in June when tourist arrivals registered a value of $93 \%$.

This sharp drop in tourist traffic is the result of the measures taken by the world governments to prevent and combat the spread of this virus. These measures aimed at restricting the movement of persons, closing land and air borders, closing commercial, public and tourist areas, as well as prohibitions on gatherings and leaving the house without justified reasons. Thus, through these measures limiting the movement of people, the economic agents operating in tourism and in the hospitality industry have registered substantial and unprecedented losses. This decrease led by itself to an increase in the unemployment rate, due to the lack of tourists, many economic agents becoming insolvent so they resorted to measures to reduce costs by restructuring staff and, finally, closing their businesses. These values translate into the loss of 67 million international tourist arrivals in the first quarter of 2020 and about $\$ 80$ billion in revenue from tourism revenues. Despite the fact that the Asia-Pacific region had the highest impact on tourism, expressed in both relative and absolute terms, a decrease of about 33 million tourist arrivals, Europe recorded the highest impact expressed in volume, 22 million tourist arrivals. Thus, until the crisis generated by the COVID-19 pandemic is overcome, tourism needs to be reinvented in order to meet the challenges, and the focus will be largely on domestic tourism, which is much easier and safer from a health point of view as a result of travel possibilities.

\section{Conclusions}

The social distancing measures imposed by governments in the hope of limiting the spread of the pandemic among citizens were fully felt by both the economic agents and the employed people. Some companies had to either narrow down

Year XXIV no. 79

March 2021 
their activity or stop it completely, these measures generating the dismissal of staff. Nor should the challenges faced by governments be denied, given that in order to mitigate the negative effects of a slowdown in economic activity in general, a number of measures were needed which led to an increase in government spending.

In our point of view, such challenges cannot be avoided, as it is the one generated by the COVID-19 pandemic. But in order to overcome them, a close collaboration between the state and the economic agents is required leading to an increase in confidence among the population regarding their safety in order to facilitate consumer decisions and relaunch the economy.

\section{References}

Burkle, F.M. (2006). Globalization and Disasters: Issues of Public Health, State Capacity and Political Action. Journal of International Affairs, 59 (2), 241-265.

Gössling, S. (2002). Global environmental consequences of tourism. Global Environmental Change, 12 (4), 283-302.

Hall, C. M. (2006). Tourism, biodiversity and global environmental change. In S. Gössling \& C.M.Hall, Tourism and global environmental change: Ecological, economic, social and political interrelationships, 142-156. Routledge.

Hall, C. M. (2020). Biological invasion, biosecurity, tourism, and globalisation. In D. Timothy (Ed.), Handbook of globalisation and tourism, 114-125. Edward Elgar.

ICAO. (2020, 07 20). Global COVID-19 Airport Status. Retrieved from ICAO Safety: www.icao.int/safety/pages/covid-19-airport-status.aspx

Nambisan, P. (2017). An Introduction to Ethical, Safety and Intellectual Property Rights Issues in Biotechnology. San Diego: Elsevier Science Publishing Co. Inc.

National Academies of Sciences, Engineering, and Medicine. (2017). Global health and the future role of the United States. The National Academies Press.

National Academies of Sciences, Engineering, and Medicine. (2018). Understanding the economics of microbial threats: proceedings of a workshop. National Academies Press.

Nicola, M., Alsafi, Z., Sohrabi, C., et. al. (2020). The socio-economic implications of the coronavirus pandemic (COVID-19): A review. Int. J. Surg. 78: 185193.

Year XXIV no. 79

March 2021 
OECD. (2020, 06). Unemployment Rates. Retrieved from OECD: www.oecd.org / newsroom/unemployment-rates-oecd-update-june-2020.htm

Ozili, P., \& Arun, T. (2020). Spillover of COVID-19: Impact on the Global Economy. SSRN Electronic Journal. 10.2139/ssrn.3562570.

Page, S., \& Yeoman, I. (2007). How VisitScotland prepared for a flu pandemic. Journal of Business Continuity \& Emergency Planning, 1 (2), 167-182.

Ram, R. (1995). Defence Expenditure and Economic Growth. Handbook of Defence Economics, 251-273.

Recchi, E., Deutschmann, E., Vespe, M. (2019). Estimating transnational human mobility on a global scale. Robert Schuman Centre for Advanced Studies Research 30, 1-10.

Say, J. B. (1803). A treatise on political economy; or the production, distribution, and consumption of wealth.

Scott, D., \& Gössling, S. (2015). What could the next 40 years hold for global tourism?. Tourism Recreation Research, 40 (3), 269-285.

Shretta, R. (2020). The economic impact of COVID-19. Retrieved from Centre for Tropical Medicine and Global Health, Nuffield Department of Medicine, University of Oxford: www.tropicalmedicine.ox.ac.uk/news/theeconomic-impact-of-COVID-19.

Smith, S. (2002, September). Old Tactics, New Threat: What is Today's Risk of Smallpox? AMA Journal of Ethics: Helping an Impaired peer, Vol. 6, Nr., 9.

Taleb, N. N. (2020, 03 26). Corporate Socialism: The Government is Bailing Out Investors \& Managers Not You. Retrieved from Medium: https://medium.com/incerto/corporate-socialism-the-government-isbailing-out-investors-managers-not-you-3b31a67bff4a.

UNWTO. (2020, 07 28). International Tourism and COVID-19. Retrieved from World Tourism Organization a United Nation Specialized Agency: www.unwto.org/international-tourism-and-covid-19

World Bank. (2012). People, pathogens and our planet: Volume 2 - the economics of One Health. World Bank.

World Bank. (2020). Global Economic Prospects. Washington, World Bank.

World Travel \& Tourism Council (WTTC) (2020 06 08). Economic Impact Reports. Retrieved from WTTC: wttc.org/Research/Economic-Impact. 